Pragmatism and the Writing of History

\title{
Histoires pragmatiques
}

A Conversation with Simona Cerutti and Yves Cohen

Roberto Gronda, Tullio Viola, Yves Cohen and Simona Cerutti

\section{(2) OpenEdition \\ Journals}

Electronic version

URL: http://journals.openedition.org/ejpap/654

DOI: 10.4000/ejpap.654

ISSN: 2036-4091

Publisher

Associazione Pragma

Electronic reference

Roberto Gronda, Tullio Viola, Yves Cohen and Simona Cerutti, « Histoires pragmatiques », European Journal of Pragmatism and American Philosophy [Online], VIII-2 | 2016, Online since 16 January 2017 connection on 15 September 2020. URL : http://journals.openedition.org/ejpap/654

This text was automatically generated on 15 September 2020

\section{cc)}

Author retains copyright and grants the European Journal of Pragmatism and American Philosophy right of first publication with the work simultaneously licensed under a Creative Commons AttributionNonCommercial-NoDerivatives 4.0 International License. 


\title{
Histoires pragmatiques
}

\author{
A Conversation with Simona Cerutti and Yves Cohen
}

Roberto Gronda, Tullio Viola, Yves Cohen and Simona Cerutti

\section{EDITOR'S NOTE}

Based at the EHESS in Paris, Simona Cerutti and Yves Cohen are among today's most authoritative advocates of a "pragmatic" or "pragmatist" approach to historical research. By these terms we mean both a focus on the practices of actors as an object of study, and a methodological concern for the ways the actors themselves justify those practices on the level of theory. The way "histoire pragmatique" has drawn on classical philosophical Pragmatism will be at the centre of this interview.

Cerutti's area of specialization is the history of modern Italy. In particular, she has studied the genesis of social groups and the transformation of the understanding of justice in Piedmont, with a focus on the link that Ancien Régime societies established between the actual possession of a status and its theorization. Her two most recent books are Giustizia sommaria. Pratiche e ideali di giustizia in una societè di Ancien Régime (Milan 2003), and Etrangers. Étude d'une condition d'incertitude dans une société d'Ancien Régime (Paris 2012).

Yves Cohen is a historian of the twentieth century. His research has been principally devoted to a comparative investigation of the 20th Century's passion for leadership and command in different geographical contexts. In his Le siècle des chefs. Une histoire transnationale du commandement et de l'autorité (Paris 2013) he compares Stalin's USSR and Hitler's Germany to the liberalism and the development of Taylorism in France and America, from the viewpoint of intellectual history and from that of a history of practices. He recently published Histoires pragmatiques (Paris, 2016) with Francis Chateauraynaud.

The interview was conducted in French and later translated by Roberto Gronda and Tullio Viola.

Roberto GRONDA \& Tullio vIOLA - Your work is frequently referred to as "pragmatic history." This notion, however, is by no means a new one: Polybius spoke of pragmatikê historia, 
Germany had pragmatische Geschichte in the tradition of Kantian anthropology. Can you tell us something about how you understand this label, and about your own encounter with "pragmatic history"?

Simona CERUTTI - Personally, I had quite an idiosyncratic introduction to pragmatic history, although this encounter was not unique to me. It was related to the experience of a group of researchers (many of whom, myself included, were pupils of Giovanni Levi), all working within the framework of microhistory, and who were at that time trying to develop an analytic approach to history. The keyword here is "analytic." We owed much to Edoardo Grendi: our goal in doing analytic history was to recover a strong form of empiricism. At the same time, it is important to note that, according to this view, empiricism is not the starting point of inquiry - its degree zero - but rather something that must be achieved. We should be wary of the familiarity we feel toward the past: rather, what we should do as historians is investigate the meaning of the words and concepts we find in the source. The idea of entering a foreign country expresses this attitude toward the past very well, as well as the kind of work needed to build up empiricism. Hence a particular attention to the sources, to the actions they report, to the fact that sources themselves are actions whose meaning should be reconstructed. I have to say that such a program of research was fostered by the criticism of positivistic social history, which was completely inattentive to the specific language of social actors.

Yves COHEN - My encounter with pragmatic history was also idiosyncratic. An indirect source of inspiration - one I have become aware of only recently - is the pragmatism of Mao Tze Tung. I was Maoist when I was young. My motto when I was seventeen was "No Inquiry, No Right to Speak!." Mao's conception of inquiry has a distinctly pragmatist tone, possibly related to the fact that he attended Dewey's lectures in China in 1919-1920. ${ }^{1}$ According to Mao, inquiry came first, even before theory. At that time, I belonged to the Proletarian left (gauche prolétarienne), and we were completely taken with this tradition of thought.

Apart from that, I would say that my encounter with pragmatic history was not only idiosyncratic, but also unique. Contrary to Simona, I did not belong to any specific group of scholars. Obviously, I paid great attention to what other people were doing around me - for instance, the social studies of science or microhistory - but I do not see any single, decisive influence that drove me towards pragmatic history. Rather, what was decisive was my discovery in 1979 of the personal archive of the director of production at the Peugeot factory, Ernest Mattern, which made it possible for me to study concrete practices.

In the early 1980s, I started to think of my work as a history of practices, largely in resonance with Foucault. On the one hand, Foucault dismissed the study of what he called pratiques réelles. On the other, in 1980, he claimed for himself the title of "historian of practices" (see, for instance, his 1978 discussion with historians published by Michelle Perrot). ${ }^{2}$ Still, his approach remains peculiar, as he claimed that practices should be analyzed from the viewpoint of discourse. But, his idea of practices being at the crossroads of what is said and what is done has been very influential for me. This made me reflect on the fact that alongside "material" acts which I was studying in industrial settings - we have linguistic ones, as pragmatic linguists said. So I started thinking about the relationship between linguistics, 
practice and history. These influences allowed me to adopt a truly analytical approach in my historical work.

Simona CERUTTI - I have to say that I see things rather differently. For me, the pragmatist or pragmatic approach is in opposition to Foucault, who I regard as a teleological historian. He is teleological because you already know who the murderer is - to quote, once again, Giovanni Levi - since the relationships of power are established from the beginning. There is an issue of Quaderni Storici entirely devoted to the analysis of the systems of charity, which highlights the difference between a historical and analytical approach to historical sources and Foucault's approach. The essays which constitute that issue study the practices within a particular institution such as the hospital, investigating in concreto the government of a hospital, the relationship between governors and government. That issue of Quaderni Storici was explicitly intended to challenge and contrast the teleological model of Foucault.

Yves COHEN - I see your point. Foucault can be read in so many different ways, and many of them are terrible! Personally, however, I do not think it is correct to speak of teleology in the case of Foucault. Some of his works grew from questioning the present and clearly triggered a retrospective history, but others opened fields of inquiry that had been little investigated by historians, such as "practices of the self," with a problem setting grounded in the past.

Roberto GRONDA \& Tullio VIOLA - This is a point on which we would like to dwell somewhat longer. Often, when people refer to pragmatism in history or in the social sciences, they see it through the lenses of thinkers who are not pragmatist in a strict sense, even though they do share some features with pragmatism. One such thinker is Foucault; another - at least here in France - is sociologist Luc Boltanski.

Simona CERUTTI - Boltanski has indeed been extremely important for me (I even wrote a review of his work). I think we can summarize Boltanski's message as taking actors seriously. Such an approach is in contrast to that which forms a large part of social history, one which aims rather at correcting and integrating the point of view of the actors. But even more than Boltanski, ethnomethodology (and in particular Garfinkel's texts) exerted a significant influence on my work: I learned much from the ethnomethodological analysis of the roles of the observer and her subject-matter, of observation and, above all, of description. This is, I suppose, the path along which I am led to action, to its creativity, to its significance: what we have to do is locate the genesis of normativity within action, not outside.

Yves COHEN - Personally, the encounter with Boltanski was not as important for me as it was for you. It might be that I consider the order of justification (which is Boltanski's and Thévenot's paramount interest) as simply one amongst many reference orders present within practices. Equally important is, for instance, how the actors formulate the situated concerns that they have when they act, and how they define the kind of relationships that they have with the institution or the group to which they belong. This is why I do not agree with those who consider this "pragmatic sociology" to be the only way to understand practices from a pragmatist/ pragmatic point of view. Take, for instance, the performativity in linguistic pragmatics: it can be used to investigate non-linguistic acts such as the spatial acts for example, going to the street to protest, or leaving one's own space to meet people in theirs, and so on. What I found more inspiring than Boltanski and Thévenot - and I do not mean to deny the importance of On justification for the present situation of the 
social sciences - was the theory of situated action as formulated by Lucy Suchman in her book Plans and Situated Action (1987). I was really impressed by the fact that, according to that approach, all that is pre-established - knowledge, norms, plans, languages, spaces, etc. - must again be tested through action. I realized that we have to re-situate action and practice, and to start our investigations from that level. The curiosity for the founders of pragmatism came much later, with the new wave of interest around 2000.

米

Roberto GRONDA \& Tullio VIOLA - Let's go back for a moment to your respective fields of research. Your texts show a strong, intrinsic link between methodology and subject-matter. Along with adopting a "pragmatic" or "pragmatist" perspective, you study historical phenomena that, however different, display a specific relationship between "practice" and "norms" or "discourses." Do you think that pragmatic methodology can also be extended to historical objects or epochs in which this relationship appears in very different ways?

Simona CERUTTI - Indeed, many of my reflections on the notion of practice originate from my work on summary justice and from the discovery of the treatment of practice made by post-glossarists. Particularly important in this context is Baldus' "pratica consumata": according to this conception of practice, the legitimacy of an action stems from its repetition, provided that there is the consensus of the actors. The discovery of this subject-matter somehow created a short-circuit between the body of pragmatist texts that provided the theoretical horizon of my inquiry and my analysis of the status of action. A second point that I would like to highlight is the idea that historical sources themselves can be conceived as actions. When conceived in this way, they are not merely - and, I would say, not primarily - reports of what happened, but rather actions that dramatically change the relationship between text and context.

Yves COHEN - You hit on an important point here. In the 20th century the relationship between theory and practice was a concrete issue, not something that only concerned scholars and historians. In my work, I investigated the history of practices that are organized by other practices, the latter being practices of the production of norms. I was fascinated by the fact that the 20th century brought about great domains of practice organized by enormous apparati such as Taylorism and Communism. At the same time, pragmatism was a philosophy that did not aim at justifying the need for the organization of practice, but rather attempted to understand its functioning. It is not by chance, therefore, that the rediscovery of pragmatism took place at the end of the 20th century, that is, at the end of a century that was essentially committed to the organization and normalization of practices. It is a historical fact and, at the very same time, a matter of concern for the historian.

Simona CERUTTI - I would like to make a distinction that may be useful here. We are dealing with two different notions: on the one hand, concrete practices and, on the other hand, pragmatism, which I regard as a method. So we could formulate the question in these terms: are practices a subject-matter or a method? I take practice to be a method: consequently, when I started reflecting on the practice of producing legitimacy and on the relationship between norms and practice, my historical investigations started thematizing something that was originally a method. 
Yves COHEN - I had to face a similar problem in my work. The difficulty stems from the fact that subject-matter and method somehow conflate. The adoption of a pragmatist method makes it possible to perceive that there are practices at work in history. Practice is not a subject-matter that we historians can freely choose among many others; it is the very substance of history. Practices - rather than theories - define how things are. Again, pride of place goes to the practices: theories are called for by practices, and not vice versa - as many believe.

Roberto GRONDA \& Tullio vioLA - In many of your answers, Yves, you seem to presume the existence of a plurality of practices. Your book argues that the 20th century is characterized by a strong dichotomy between practices that produce normativity, and thereby control other practices, and practices that simply apply what has been decided elsewhere. The recognition of this dichotomy paves the way for the study of the practical side of leadership, as well as for the analysis of the normative aspects embedded in accepting the decisions of the authority in charge of the production of normativity. So, you seem to be led to a slightly paradoxical conclusion: it is like you were saying that it is precisely such a split that makes us realize that the two kinds of practices cannot be split.

Yves COHEN - You are perfectly right, but it is not a contradiction for which I can be held responsible! It is a contradiction of the actors: it is a contradiction in the things themselves! Take, for instance, management. Management has a strong, almost natural relationship with a practical attitude. It does not care much about theory. Managers are very interested in the theory of management - Taylorism, for instance - and they produce theory. However, they know that it is not theory that makes the difference, but rather the solutions that can be found by analyzing the concrete problems at stake: on the spot, theory may help or not. One excellent example is the Berliet factory. Berliet wanted to be a Fordist and a Taylorist; he built a huge factory replete with machines coming from the United States. He imported American normativity, so to say. But the factory never worked because the steel that was necessary to build the automobiles was not the same that was available in the United States, and he could not import all the steel he needed from America. So, his project turned out to be a disaster, and simply because he wanted to apply a theory! He failed because he privileged theory over the situated conditions. In Stalinist communism we should always keep in mind the distinction between Stalinism and Maoism on this specific viewpoint - we have the same idea of a practice controlled and directed by theory. Nonetheless, if we study its practice, we see on the one hand that it is no less pragmatic than the others, since theory was always called by the demands of the concrete situation. The control by theory was just a propaganda argument.

On the other hand, this approach has been harmful for the social sciences, especially here in France. For a long time, theory was said to be in charge of telling us what is real - what the essence of class conflict is, for instance. So, to go and look for what was happening in the concrete practices was deemed as a waste of time. The appeal of theory blocked the road of inquiry. Take, for instance, the introduction written by Henry Wallon to the important collective book À la lumière du marxisme (1938-39). In this text, we see clearly how Wallon formulates and constitutes what we might call the "ban of inquiry." Its bearings on French social sciences have still to be appraised.

Simona CERUTTI - May I ask you a question? From what you have just said, it seems that you take pragmatism and inquiry as being substantially equivalent, as if they 
were the same thing. When you talk about Mao, for instance, you say that he was pragmatist because he praised inquiry. I am not sure that this is correct.

Yves COHEN - No, I do not think that pragmatism can be boiled down to inquiry. Among other things, pragmatism is also the idea that we should not take categories for granted, and that we should investigate the modes of constitution of things. Another important aspect is the study of the relationship between practice and theory, in the way that it is perceived by the actors. I studied that problem as it relates to some contemporary constellations of events such as Stalinism and Fordist production practices. And the problem is connected to another important issue, namely the relationship between discourse and practice. I have to say that I am deeply annoyed by how people now use and abuse the expression "let's study the discourse and the practice of" - say, the discourse and the practice of social protection. I am not saying that we should get rid of the conceptual couple discourse/ practice, nor that we should blur the distinction. The other way around! We should delve deeper into that relationship. As you say, we cannot simply pit norms (or discourses) against practices. According to Foucault, discourse is a discursive practice, and it is for this very reason that discourse becomes relevant. At the same time, when we turn our attention to concrete practices (for instance, the practices of organization of work), we see that they have a strong material and spatial dimension, but they are constitutively accompanied by discourse. This is a real pluralism of practices. Practices turns out to be a plurality of interlocked practices: practices are made, among other components, by discourses - which are practices!

Simona CERUTTI - This is also the idea of looking for validation (légitimation) in concrete practices, which is an important aspect of what we do when we read historical sources. I think this is a truly pragmatist tenet. Reading the sources as actions that raise a claim for legitimacy dramatically changes the way in which we do history.

By legitimacy I do not mean formal legitimacy. Legitimacy can be informal, and in the latter case the claims for legitimacy do not refer to a legal order. The point is that actions may create a social status, instead of simply mirroring something else. If you stress the continuity between action and interest, and conceive of actions as sort of emanations of the interests of the agents - that is, of their identity and their social condition - then you can actually develop an analysis of actions. It might even be possible to have an analysis of actions in terms of practices.

This goes back to the criticism that has been raised against E. P. Thompson: If you create a continuity between action and individual interest, and conceive of action as a sort of emanation of individual interests (or of their social position, etc.), you end up with a conception of action which you might certainly call "practice," but which remains the reflex of something that already exists - such as social order, hierarchy, etc. If, in contrast, you approach the reports of actions that you find in sources as something that contains a reason in itself, and is not a mere overflow of experience, but rather the organization of an experience - in that case, you have broken the continuity between action and social order. You have introduced a gap, a cleavage between the two layers. Therefore, you are in the position to reflect on the creativity of action as a necessary condition for the production of claims of legitimacy, 
normative demands, etc. By breaking the chain that directly links action to individuals, you can start looking at action as the product of a specific situation.

Yves COHEN - I totally agree with you. But I would like to complicate the picture slightly. I think that it is incorrect to say that everything that is said or written is discourse. In one interview given to Roger Pol-Droit, Foucault remarks that it is important to distinguish things said (choses dites) and discourse. Things said are what we do when we talk to each other in a boulangerie: "How much is this croissant?" There is no discourse here; there are just things that are said.

Roberto GRONDA \& Tullio vIOLA - Moreover, it seems to us that discourse has at least two different meanings. On the one hand, it may refer to what you find in the sources; on the other, it means theory. In turn, theory can be investigated from two different perspectives: it can be studied historically - as the subject-matter of the research - or as the overall framework of the historian. So, there is the relationship between discursive practices and material practices, and there is also the relationship between theory and practice.

Yves COHEN - This was precisely my point! In the 20th century, the relationship between theory and practice was considered a historical matter; but it is not an issue that concerns only the historian. For instance, the communists used to say that words do not matter, only facts matter. It was an attempt, which we now perceive as meaningless, to contrast words and facts. But this is a trick, a fraud! What is interesting from my point of view is to understand, historically, whence the idea that words do not matter comes. I feel that there is something extremely important related to the effort to weaken and erase free thinking. If you do not think that words are acts of speech, it follows that words do not matter. The fact that you have the right to speak will not make any real difference. Put in this form, it is clear that this is an argument of power through which practices can be organized. This is something that we should clarify historically in order to free ourselves from its grip.

Simona CERUTTI - With regard to the notion of practice, a recent article by Roberto Frega (who is a philosopher) shows an interesting difference from the perspective of the historian. By this, I mean the distinction that Frega draws between action and practice. Action, he says, has to do with the individual, while practice is collective. However, modernist historians are often confronted with sources that showcase a distance between action and individual responsibility. Let me offer an example: the case of wedding pledges in the 16th and 17th centuries. Sources tell us of cases in which a girl was sitting, doing nothing, and a man would throw a ring at her. The interesting point is that if she was touched by the ring, that could count in court as a form of "action" and a valid proof of the engagement. The rationale here is that she did not react against the action performed by the man. She is "struck" by the action, and is therefore "held" by that action, provided the action unfolded "without contradiction" - this is the crucial phrase. If an act is produced "without contradiction," it can change social statuses, irrespective of individual intentions. This example suggests an answer to your question about the dialogue between historians and pragmatist philosophers: In this case, in fact, we can see that there is a gap between action and individual, which goes against twentieth-century philosophy as a whole.

Roberto GRONDA \& Tullio VIOLA - This is interesting also from a methodological perspective: Pragmatist philosophers tend to take "action" or "habit" as universally valid concepts, although they also endorse a genealogical approach to philosophical categories. 
Conversely, you are now insisting on the role of pragmatism as a method that prevents us from taking our categories for granted and from projecting them all too easily onto other historical periods.

Simona CERUTTI - I think so, and let me further expand on the previous example. My current work centres on the notion of responsibility: responsibility and justice in the long term. Now, while the term "responsible" as an adjective has always existed, the word "responsibility" suddenly appears at the end of the 18th century. And I suspect - although this is yet to be demonstrated - that there is a relationship between the sudden introduction of that word and the birth of the concept of action as related to individual intention. To test this hypothesis, I have been working in territories such as bankruptcies and merchant insurances, to explore which conception of "responsibility" is at play therein. And what I noticed is that the idea of "intention" is always related to culpability, not to responsibility. This means that the concept of action is somehow autonomous. People were more concerned with putting the action right than with finding a responsible individual or culprit.

Roberto GRONDA \& Tullio VIOLA - Let's delve a bit deeper into the relationship between practice and normativity. You both insist that we should not draw a neat divide between practices and norms, because a practice can always "turn into" a norm. Yet this is hardly enough to acquiesce philosophers, who are on the lookout for precise ways to define when, exactly, a practice turns into a norm. Can you single out any qualitative difference between the two dimensions?

Simona CERUTTI - Sources of the ancien régime suggest that an essential aspect of actions' transformation into norms is consensus and repetition over time - I mean the fact that an action has unfolded in a continuous way over time, backed by consensus. This dynamic somehow triggers a process of generalization. There is a moment in which actions are granted a weight as precedents; they are recognized as having a general purport. Which is interesting, because today we tend to conceive of the path from particularity to generality as related to accumulation, not to repetition and consensus. (Think again of the distinction between individual actions and collective practices.)

Roberto GRONDA \& Tullio VIOLA - We are close to the problem of convention, aren't we?

Simona CERUTTI - We certainly are, although a very interesting article by Louis Quéré, A-t-on vraiment besoin de la notion de convention?, ${ }^{3}$ suggests that we do not need to talk about convention if we undertake an analysis of action. Action creates convention. As for me, I would give pride of place to the idea of consensus - and ultimately, to the public. Consensus has the power to transform the status of action. Now the question is: In contemporary societies, does that suffice? Do we need a formal act of recognition that turns an action into a convention? In ancien régime sources, this is continuously evoked. "I do this without contradiction" - this phrase may become a bit of evidence in all sorts of territorial conflicts, etc. A recent book by Tamara Herzog, Frontiers of Possession, shows that all national boundaries in ancien régime are established by specific acts of ownership, which have unfolded without contradiction.

Yves COHEN - I have a slightly different viewpoint. I have always been puzzled by the conventionalist emphasis on agreement: it seems to me that this is an overly irenic view of social life. I would rather stress the confrontational nature of society. Which 
does not mean that overt conflict, or war, is all-pervasive. Confrontation often leads to compromise. Even authority may be conceived in terms of the compromises reached in order to let things work. Authority is shaped in open conflict and settled in its breaks, forming a compromise (which may also be implicit, not formal). So this is my view of things: a confrontational dimension, with moments of overt conflict and moments of compromise.

Roberto GRONDA \& Tullio VIOLA - Is this the reason why you emphasize that the notion of ends is not part of the definition of the notion of practice?

Yves COHEN - Exactly. I want to reject views such as that of McIntyre's, who sees practice first of all as a "community of ends." This cannot work. All the more so as there are institutions which, historically, have been invented in order to put together people who do not share the same ends - to have them contribute to the same practice. Think of enterprise, or even of war! People might not have ends in common apart from production or war deeds.

Simona CERUTTI - True, but let me reply: "consensus" does not mean that people always agree. Rather, it is the condition - the condition declared, or put on display to legitimize an action. But I agree that this is a relation of power. You silence the other voices. This is far from being the same as to say that everybody agrees. But you may nonetheless say that there is consensus.

Yves COHEN - So, this is perhaps what I call compromise.

Roberto GRONDA \& Tullio VIOLA - In any case, both of you insist on the productive character of conflict for a reflection on normativity. Simona, you hold that the conflict between two norms represents the juncture from which new norms or new actions are created. And you, Yves, explicitly remark that normativity is always directed "against" former norms.

Yves COHEN - Let us start off from Roberto Frega's useful invitation to look at practices as themselves normative. ${ }^{4}$ I agree with him, but I would add that the normativity of practices is always a counter-normativity: an opposition to already existing norms. Taylorism is a good case in point: it is a "device" to produce norms, which have been established at the expense of other norms: ordinary norms that regulated labour; norms that workers had agreed on and fabricated by themselves, and which, at the same time, protected them from the threat of entrepreneurs. A similar dynamic characterized Communism, which aimed at destroying the ordinary ways in which masses fought for themselves and the norms of typical social fights. By imposing other forms of normativity, Communism wanted to steer masses toward revolution and turn history for the better. So, power always establishes norms against other norms. At the same time, ordinary practices always fabricate norms. I think we are a bit limited by the classical idea of a norm as something that enables and constrains. This overlooks the fact that every action entails a commentary to its norm; a criticism of the norm, as limited as it may be. Three aspects: norms are enabling, constraining and open to criticism.

Simona CERUTTI - This reminds me of a notion which the urban sociology of the last ten years has been working on - namely the notion of acts of citizenship - as a means to complicate the link between official discourses and everyday interactions. Lately, I have been to Sciences Po to give a lecture on political mobilization. And as I talked about labourers, people from the audience objected: This is not politics! The problem here is the distinction between politics and everyday action. If a person says to 
another: "Don't jump the queue please - it's not ok!," this is an everyday conversation; but it is also "encrusted" with criticism and normativity. This particular point is the object of very recent sociological investigations. And while some social sciences are caught off-guard by this overlapping of ordinary and normative acts, other social sciences are not. For they show that this distinction is not essential; it simply marks a difference of degree. In this sense, acts of citizenship are practices within the political space, which carry criticisms and make propositions.

Yves COHEN - Indeed. And a similar discourse applies to the worker on the line. Sometimes, the amount of criticism and proposition is an infinitesimal dimension of practice. But it is there all the same. Sartre used to say: There is never a total absence of freedom. There is always a small fragment of it. I would say: a small fragment of criticism (or interpretation) of the norm. A fragment that sometimes grows into overt resistance, contestation, even revolution. No norm can be other than counternormative.

Simona CERUTTI - But if you say "counter-normative," you end up pitting one norm against the people that oppose it. I think, instead, that there are many norms. We live in a thick fabric of norms; we face a huge amount of normative centres. The state is one of them. The family, the couple, the workplace are others. This normative thickness of everyday life counters the traditional understanding of normativity, but also that of "counter-normativity." I don't mean to say that there is no class struggle. But I do believe that we constantly face a plurality of normative universes. I found myself working on sources that are similar to those on which E. P. Thompson drew to study labour force. Thompson interpreted phenomena such as the Saint Monday, ${ }^{5}$ which was the workers' resistance to those norms that dictated the work schedule. In the cases on which I have been working, however, the Saint Monday was not so much a resistance to the norm as a parallel organization of working time. During Saint Mondays, people wouldn't stay at home with their arms folded, just to "resist." Rather, they interpreted it as a workday in which they would walk into other boutiques, would organize the movability of workers, etc. But this system was, in turn, a normative system. There were people fighting against that system as well.

Does this change anything? It seems to me that reconstructing the plurality of norms amounts to admitting that conflict is everywhere. The space of conflict is the space of interrelation. A source is not a description, but is addressed to someone. And very often, it entails a conflict - which is not necessarily a political conflict, but it is a conflict all the same.

Yves COHEN - We are less distant in our understanding than you think. I wrote an article on "multiple authorities," which dovetails with your idea of a multiplicity of normative universes.

Roberto GRONDA \& Tullio VIOLA - A last question on the issue of normativity. In your analyses, actions that have a normative force tend to acquire a symbolic force that goes beyond their pragmatic dimension. In the case of ancien régime acts of ownership (Cerutti), we read about people who go to the houses they wish to own and perform symbolic actions, such as repeatedly opening doors and windows, in order to signal performatively that the house is theirs. In Cohen's book, the commandment of the chef, when it is embodied into a concrete artefact (for instance, a drawing or a plan) tends to acquire an autonomous allure, to be revered as an artwork. Alternatively, the very image of the chef may become the 
object of symbolic production. These phenomena seem to point to a tight link between the pragmatic and the symbolic.

Simona CERUTTI - I don't know - I really don't - if I would talk about "symbolic" action here. Maybe a better term is ritual, which also encompasses the problem of the effectiveness of action. The conditions of effectiveness of a regular action which I have been singling out in my work - i.e., its unfolding without contradiction, its being repeated over time, etc. - may also be seen to characterize ritual action. Therefore, ritual action may be studied from the viewpoint of normative effectiveness. This certainly opens up an enormous field of research.

Yves COHEN - When looked at from the viewpoint of practice, institutional statuses, scientific utterances, concepts and social categories no longer appear as fixed entities. Rather, they resemble formal elements that need to be continually reconceived, re-composed, re-justified. The point is not to deny existence to forms by dissolving them into practices; rather, it is to see them as a stage of practical activity, or as a manner of composing the situation in which action unfolds. To talk about these elements we may certainly use the word "symbolic"; but Simona's use of the word "ritual" is very much to the point, because the ritual is always a modality of practice; it points to a formal moment within practice.

So, for instance, the relationship I establish between plan and situated action is not aimed at destroying the autonomy of the plan. Rather, the plan appears within the universe of action as one component amidst others - like norms, scientific utterances, etc. Once again, historians of science may come in helpful. They suggest to stop looking at knowledge in an abstract sense, and to start looking at the way knowledge is effectively produced, and then at its concrete deployment within action, at the ways it is questioned and re-articulated. The point is not to deny existence to formal elements, but to study them as components of the dynamics of practice.

米

Roberto GRONDA \& Tullio VIOLA - A last, methodological question. As both of you conceive it, pragmatic history primarily hinges on the categories deployed by actors. This stance has deep-seated roots in pragmatist epistemology. At the same time, another major insight of pragmatism is the emphasis on the habitual dimension of action. From this angle, the purport of action always in part escapes the consciousness of actors. And in order to reconstruct it, we need the external perspective of observers. Do you think it is possible to strike a balance between these two views?

Yves COHEN - I would put the same point in a slightly different way. The main gist of our attempt to develop a pragmatic history is related to the difference between our approach and that of another way of doing social science - a traditionally Durkheimian way, we might say - in which scholars build up structures, categories of social determination, and so forth. Now, if we want to grasp all the potentialities of our research, I think we should insist on the analytical emphasis on practices, whose relevance to the study of structures and historical contexts has not been completely unpacked yet. The question we should ask is: What is the mode of existence of structures - the materiality of their existence? We have been looking for social structures for so long, so many centuries! We should keep going in the other direction and studying the creativity in, and of, the practices on any scale. 
The methodological condition of pragmatic history is a certain quality of sources. You cannot do pragmatic history if you do not have sources that "report" the activities of people. And not all sources are well-suited for this enterprise. This is why I would not dream of denying that other ways of doing history are possible: I just insist on my own way of doing it, which hinges on the attempt to see sources as actions, as an element that aims at doing something in its practical context.

In any case, the question of actors' versus observers' categories is crucial. Bringing out the categories of actors is a necessary condition if we want to give justice to the "alterity" of history. This, however, does not prevent us from using our own categories as well. Only, we ought to render explicit the uses we make of both sets of categories. But there is yet another, pragmatic argument, which goes back to Polybius: I think that, when doing pragmatic history, we need a certain familiarity with the experience we study. I often think of what Marc Bloch said about writing the history of watermills. He said: Go to the countryside; you will find ruins of watermills, and even if they're not those you are studying in your historical research, it will nonetheless give you an idea of what a watermill was. Now that's not exactly what I'm talking about, but... Even if history becomes something like a "metaphor" of an experience that one has already had, I nonetheless think that we do need a relationship with experience as a basis to construct alterity. I have, for instance, worked in a factory. Back then I was Maoist. I was a worker, I was engaged in politics, and I then reflected as a historian on the same experiences in a remote past. The way I am dealing with practice is undoubtedly marked by this

Simona CERUTTI - For me, on the contrary, the metaphor of the past as a foreign country is predominant; history should be made against the grain of sources. This is why I speak of empiricism as the result of inquiry, not as its degree zero. The point is to create distance; to undergo a process of estrangement, so as to perceive things that would otherwise appear too close. Of course I can say: I've been to the market. But what is a market, in the 18th century? I seek a sort of denaturalization of the object.

Yves COHEN - Well, I do think, instead, that we need some experiential relationship with the object; but the point is that this relationship does not dictate the economy of inquiry! Historical work remains a work of fabrication, of strangeness. Still, we need some sort of proximity to practice. How would you go about making an acceptable analysis of the practice if you have no idea whatsoever of what kind of practice you're dealing with?

\section{NOTES}

1. Cf. Emmanuel Renault, (2013), "Dewey, Hook et Mao: quelques affinités entre marxisme et pragmatisme," Actuel Marx 54, 138-57; Hongliang Gu, (2014), "L'influence de Dewey sur le jeune Mao," Actuel Marx 56, 124-32. 
2. Michel Foucault, (1994), “Table-ronde du 20 mai 1978," in M. Perrot (ed.), M. Foucault, Dits et écrits, vol. 4, Paris, Gallimard, 20-34.

3. In Reseaux, (1993), XI/62, 19-42.

4. Frega R., (2013), Les sources sociales de la normativité. Une théorie des pratiques normatives, Paris, Vrin.

5. Saint Monday is the traditional phenomenon of absenteeism on mondays.

\section{AUTHORS}

\section{ROBERTO GRONDA}

Università di Pisa

roberto1gronda[at]gmail.com

TULLIO VIOLA

Humboldt-Universität zu Berlin

tullio.viola[at]gmail.com

\section{YVES COHEN}

EHESS, Paris

yves.cohen[at]ehess.fr

SIMONA CERUTTI

EHESS, Paris

simona.cerutti[at]ehess.fr 